\title{
Development of impact functions on regional paddy rice yield in Japan for integrated impact assessment models
}

\author{
Toshichika IIZUMI, Masayuki YOKOZAWA, and Motoki NISHIMORI
}

(National Institute for Agro-Environmental Sciences, 3-1-3 Kannondai, Tsukuba 305-8604, Japan)

\begin{abstract}
For this study, we developed and validated two types of impact functions on regional paddy rice yield in six regions of Japan. One is simple, and the other is slightly detailed. An impact function has the following features: (1) it is a look-up table that shows the quantity of interest (regional paddy rice yield in this study) in response to various forcing conditions; (2) it is provided by a mechanistic but heavy computational-load model; and (3) it is implemented in integrated impact assessment models to reduce the simulation time. The developed impact functions will be submitted for use in integrated impact assessment models and will contribute to examining the target level of stabilization on greenhouse gas emissions. The impact functions were compared with the observation and the conventional crop model simulation (full-simulation). The slightly detailed (simple) impact function agreed with the observation with a mean-absolute-percentage (MAP) error of $7.8 \%$ (7.7\%). Under warming conditions, the slightly detailed (simple) one was comparable to the full-simulation with a MAP difference of $4.5 \%$ (4.6\%). The majority of the difference arose from the temperature fluctuation within a short time period of less than two months. These results indicate that the application of the impact functions is permissible for assessing the impact of the average climate change on regional yield. However, the impact functions tend not to be a very reliable tool for assessing the impacts of extreme climate events and interannual climate variation on regional yield.
\end{abstract}

Key words: Impact function, Integrated impact assessment models, Japan, Regional paddy rice yield.

\section{Introduction}

The Intergovernmental Panel on Climate Change Forth Assessment Report (IPCC, 2007) concludes that most of the observed increase in global average temperatures since the mid-20th Century is very likely to be due to the observed increase in anthropogenic greenhouse gas (GHG) concentrations. The increase in temperature and induced changes in climate systems have caused concern relating to their impacts on wide-ranging sectors, including agriculture. The United

Received; July 16, 2008.

Accepted; February 2, 2009.

Toshichika IIZUMI

Agro-Meteorological Division

National Institute for Agro-Environmental Sciences

3-1-3 Kannondai Tsukuba, Ibaraki 305-8604, Japan

'E-mail: iizumit@affrc.go.jp
Nations (1992) has the goal of stabilizing the GHG concentrations in the atmosphere to a level that would prevent dangerous anthropogenic interference with the climate system (referred to as the level of stabilization). To determine a target level of stabilization, the use of integrated impact assessment models (hereafter, integrated models) is valid for considering the overall problem as part of efforts to minimize the negative impacts of climate change on the socioeconomic situation and the minimize the cost relating to the reduction of GHG emissions.

To that end, an integrated model, the AIM/Impact [Policy] (Hijioka et al., 2006a), was developed. The integrated model uses the impact functions to simulate the impact of a GHG emission control policy on wideranging sectors with a small computational load. The general features of the impact functions are as follows: (1) it is a look-up table that shows the quantity of inter- 
est (regional paddy rice yield in this study) in response to various forcing conditions; (2) it is provided by a mechanistic but heavy computational-load model; and (3) it is implemented in very heavy computational-load models (i.e. integrated assessment models) to reduce the simulation time. At present, impact functions on country-level crop production (Hijioka et al., 2006b) and global water resources (Hanasaki et al., 2007) are available.

In response to a call for impact functions, we developed two types of impact functions on regional paddy rice yield in six regions of Japan, which were the look-up tables of the regional yield response to changes in temperature, insolation, atmospheric $\mathrm{CO}_{2}$ concentration, and planting date, provided by a simple process-based crop model. The defined regions are Hokkaido/Tohoku, Kanto, Hokuriku/Tozan/Tokai, Kinki, Chugoku/Shikoku, and Kyushu. Okinawa was eliminated because of its limited acreage of paddy rice fields. The developed impact functions were compared with the observation and the results obtained from the conventional simulation of a crop model (referred to as a full-simulation). The description of the developmental procedure and the validation of the developed impact functions were the purposes of this study.

\section{Data and Method}

\subsection{Data}

\subsubsection{Current and future climate data}

Data relating to current and future climate were used as the forcing data of the crop model. The MeshAutomated Meteorological Data Acquisition System (AMeDAS) data, obtained from the National Institute for Agro-Environmental Sciences (Seino, 1993), were used as the current climate data. The original AMeDAS data were provided by the Japan Meteorological Agency (JMA). The climate data were processed as follows to provide the forcing data for each prefecture. Firstly, the daily mesh values of the climate data over a paddy field were gathered and averaged over the meshes and the geographical distribution of the paddy fields obtained from the digital numerical land information provided by the Geographical Survey Institute. Secondly, the mesh-averaged value was calculated for 25 years $(1979-2003)$ at a daily time scale. Thirdly, the 25-year climatological-mean was calculated from the daily time-series of mesh-averaged climate data. These procedures were conducted for the daily maximum and minimum temperatures $\left[{ }^{\circ} \mathrm{C}\right]$ and daily total insolation
$\left[\mathrm{MJ} \mathrm{m}^{-2}\right.$ day $\left.^{-1}\right]$. The data concerning the climatological mean for three climatic elements were defined as the baseline climate.

As the projection of possible future climate conditions, the WCRP-CMIP3-Multimodel dataset (Meehl et al., 2007) was used. Nine projections performed by seven atmosphere-ocean coupled general circulation models (GCMs) were downloaded, and the coarse grid-point values of the GCM are interpolated to the terrain of Japan with a $10-\mathrm{km}$ mesh size (Okada et al., 2008). The temperature difference between the future and present in a GCM were added to the baseline climate for temperature. Meanwhile, the ratio of irradiance between the future and present in a GCM were multiplied to the baseline climate for insolation with the constraint of global solar radiation at the top of the atmosphere $\left(R_{\mathrm{top}}\right)$. We set the maximum of the daily insolation at the surface at $50 \%$, meaning the irradiance value was replaced by the maximum value when the value of irradiance after multiplication exceeded the maximum value. The projections of GCMs used for this study were performed by the CGCM3.1 (including three ensemble members: Flato and Boer, 2000), the CSIRO-Mk3.0/Mk3.5 (Gordon et al., 2002), the GFDL-CM2.0 (Delworth et al., 2006), the MIROC3.2.MEDRES and HIRES (K-1 model developers, 2004), and the MRI-CGCM2.3.2A (Yukimoto and Noda, 2002).

\subsubsection{Atmospheric $\mathrm{CO}_{2}$ concentration data}

Data on the atmospheric $\mathrm{CO}_{2}$ concentration were also used as the forcing data of a crop model. The data, observed by the JMA at the Ryori site, were obtained from the World Data Center for Greenhouse Gases (WDCGG). Annual data for 24 years (1984-2007) were available. We extrapolated the obtained annual data into the period 1979-1983 by using the temporal linear regression curve. A single piece of data of the atmospheric $\mathrm{CO}_{2}$ concentration was used for all prefectures. Regarding the future scenario on the atmospheric $\mathrm{CO}_{2}$ concentration, we used emission scenarios under the A1B and A2 of the Special Report on Emission Scenarios (SRES: IPCC, 2000).

\subsubsection{Actual heading day, yield, and yield trend data}

Data on the actual heading day, yield, and yield trend for 25 years (1979-2003) for each prefecture were obtained from the crop statistics provided by the Ministry of Agriculture, Forestry, and Fisheries, Japan (MAFF). The yield trend data included in the 
crop statistics are estimates using the non-parametric regression method and based on the assumption of normal weather conditions (MAFF, 1998). We removed the yield trend from the actual yield data to focus on the climate-crop relationship because the yield trend reflects the progress in the level of cultivation practices, the introduction of improved cultivars, and the promotion level of agricultural infrastructure. The detrended yield data were gathered, averaged over prefectures and used as the observed data. Detrending was not performed for heading day data because data on the heading day trend were not available from the crop statistics.

\subsection{Crop model for irrigated paddy rice}

A newly developed simple process-based crop model for irrigated paddy rice, the Process-based Regional-scale Rice Yield Simulator with Bayesian Inference (PRYSBI: Yokozawa et al., 2006; Iizumi et al., 2009), was applied to both the impact function and full-simulation approaches. The PRYSBI model estimates the probability density function (PDF) of the paddy rice growth and potential yield under given forcing data with the perturbed-parameters-ensemble (PPE) procedure. The range of the perturbed value is given by the posterior distribution, obtained from the Bayesian inference (see lizumi et al., 2009 details).

Fig. 1 shows the flow of the PPE procedure, which consists of three steps: Firstly, the set of parameters was randomly sampled from each posterior distribution of parameters; Secondly, the heading day and yield were simulated on the basis of the sampled set of parameters and given forcing data; and thirdly, the PPE statistics of the simulated heading day and yield were calculated and output. The number of PPE members was 3,000 for both approaches and the use of the PPE procedure permits the PRYSBI model to simulate the heading day and yield more accurately in comparison with the use of a set of single optimal parameters (Tao et al., 2009). In addition, the use of the PPE procedure can quantify the uncertainty of yield prediction associated with the model parameters (Iizumi et al., 2009). For these reasons, we used the PPE procedure instead of the optimal parameters. For this study, the median, 25-, and 75-percentiles of the PPE members were used to summarize the form of the obtained PDF on the heading day and yield, which is often non-Gaussian. The percentiles were used to calculate the uncertainty range (the distance between the 25- and 75-percentiles).

Fig. 2 indicates the modeled relationships between the average daily maximum temperature during the flowering period and the spikelet fertility of paddy rice. The flowering period is defined as the period of developmental index ranging from 0.96 to 1.20 (Nakagawa et al., 2003). The relationship modeled by Horie et al. (1993) is also plotted for reference purposes. The PRYSBI model follows the doubled $\mathrm{CO}_{2}$ case path, modeled by Nakagawa et al. (2003), but allows

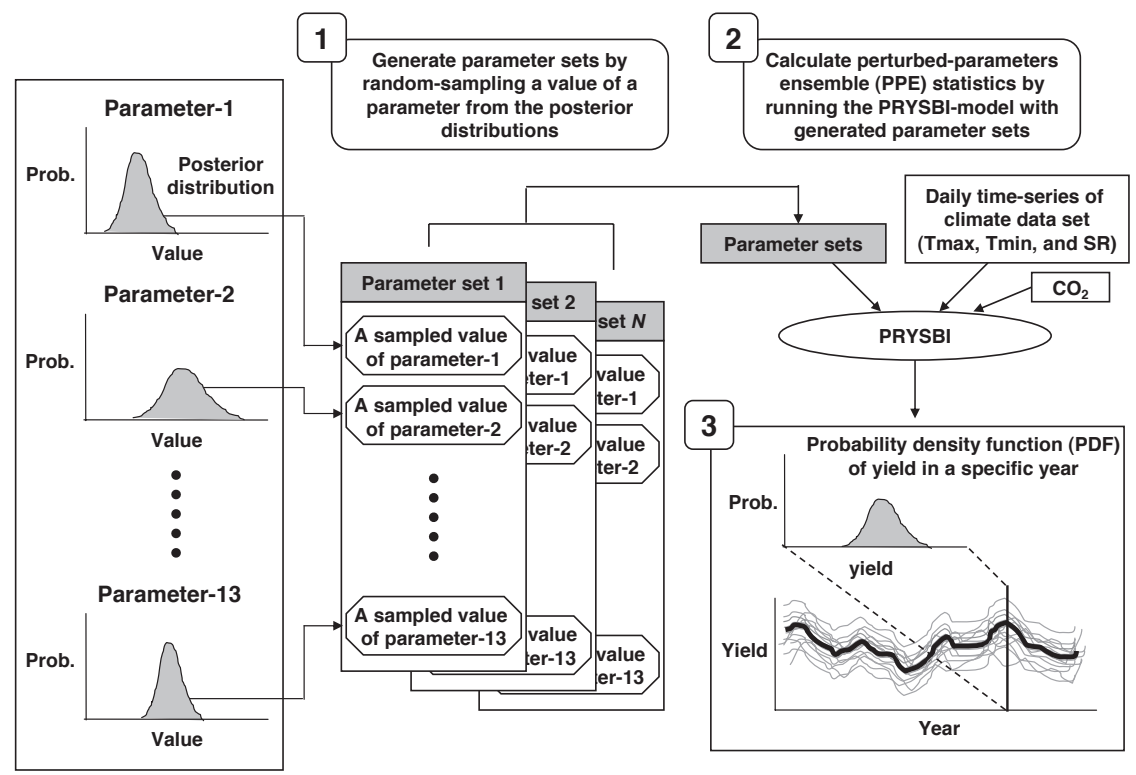

Fig. 1. Schematic diagram of perturbed-parameters-ensemble procedure of the PRYSBI model. 
estimates to be distributed within a certain definite range. Such probabilistic treatment was performed by the PPE procedure. As Iizumi et al. (2009) reports, the yield data obtained from the crop statistics do not include sufficient information for a satisfactory

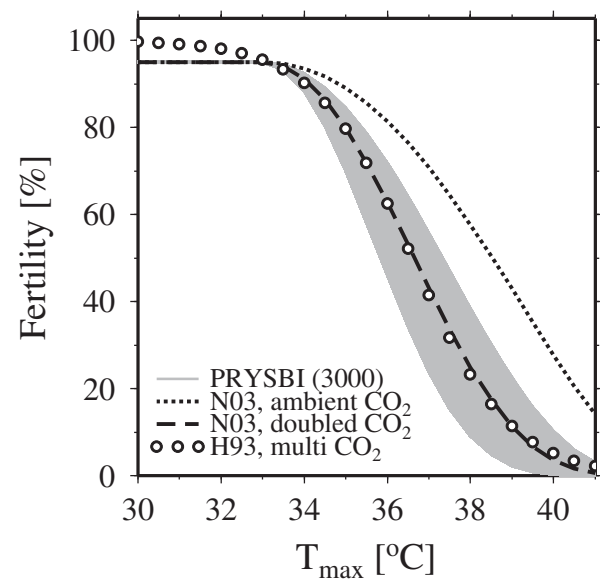

Fig. 2. Modeled relationships between average daily maximum temperature during flowering day, $\mathrm{T}_{\max }$, and spikelet fertility of paddy rice. Gray lines indicate 3000 paths of the PRYSBI model. Dotted and solid dashed lines indicate the ambient $\mathrm{CO}_{2}$ case path and doubled $\mathrm{CO}_{2}$ case path, modeled by Nakagawa et al. (2003) (N03), respectively. The circle indicates the path, modeled by Horie et al. (1993) (H93). constraint of the parameter value on spikelet fertility under high temperature conditions. Thus, the PRYSBI model simulates the spikelet fertility with the threshold temperature of $33^{\circ} \mathrm{C}$ (Nakagawa et al., 2003), obtained from the chamber experiments and the fairly broad posterior distribution on the curvature factor of spikelet sterility.

\subsection{Impact function approach}

Fig. 3 shows the developmental procedures of two impact functions and a full-simulation. The PRYSBI model was applied to the development of two impact functions on regional paddy rice yield in six regions of Japan. One was simple (4-element), and the other was slightly detailed (6-element) because the treatment of summer temperature in the 6-element one was better than that in the other. In this development, the climate data used included only information on climate change presented on the monthly scale to meet the specifications of the integrated model (i.e. AIM/Impact [Policy]). The daily fluctuation of the climate data used were derived from the baseline climate.

The various forcing data were generated by modifying the baseline climate with the bottom-up approach (Wilby et al., 2004). The temperature change was added time-independently to the baseline temperature, whereas the percentage change in insolation was multiplied time-independently to the baseline insolation with the constraint of $50 \%$, which was the maximum of the daily insolation at the surface. The range and

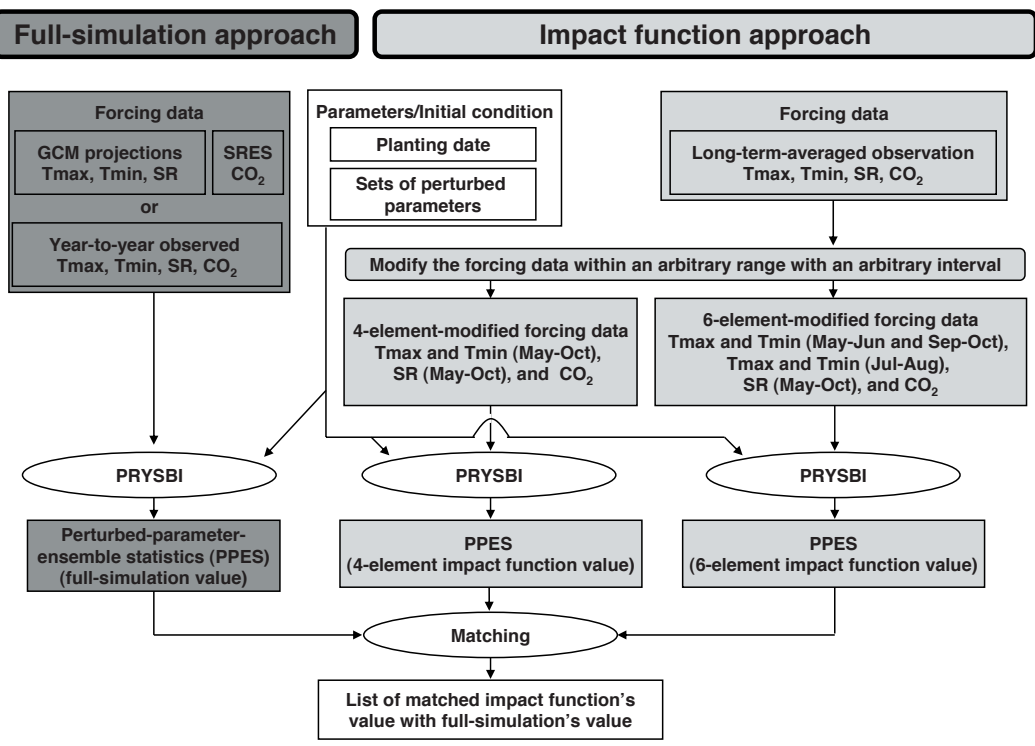

Fig. 3. Developmental procedures of the two impact functions and the full-simulation. 
interval of the forcing data were as follows: 350 to 850 ppm with a 50-ppm interval in the atmospheric $\mathrm{CO}_{2}$ concentration (11 levels); -2.0 to $6.0^{\circ} \mathrm{C}$ with a $0.5^{\circ} \mathrm{C}$ interval in the change in the daily maximum and minimum temperatures during the warm season (May-October for the 4-element one and May-June and September-October for the 6-element one) (17 levels); -2.0 to $6.0^{\circ} \mathrm{C}$ with a $0.1-^{\circ} \mathrm{C}$ interval in the change in the daily maximum and minimum temperatures during summer (July-August) (81 levels); 80 to $115 \%$ with a $5 \%$ interval in the percentage change in the daily total insolation during the warm season (May-October) (8 levels); and -21 to 21 days with a 7-day interval in the shift of the planting date (7 levels). In total, in the 6-element impact function case, 848,232 forcing data were considered for each prefecture to provide the impact function.

Hanasaki et al. (2007) set the range of temperature change from -5 to $15^{\circ} \mathrm{C}$. Our range was comparatively limited, but the range of -2.0 to $5.6^{\circ} \mathrm{C}$ was found in the temperature anomaly in the warm season around Japan in the nine climate projections used (Okada et al., 2009). We believe that the assumed range was sufficient for this study. Regarding the insolation, our range was wider than that presented by previous studies, i.e. 90 to $110 \%$ in the end of 21st Century under the A2 scenario (Iizumi et al., 2008) and 92 to $107 \%$ in the end of 21 st Century under the A1B and A2 scenarios (Okada et al., 2009). Regarding the shift of the planting date, we referred to Toritani et al. (1999) and set -21 days as the maximum of early planting. However, since reliable information related to the maximum of late planting was unavailable, 21 days was set as the maximum.

In the impact function approach, the yield simulation were conducted by searching and selecting the most similar conditions to the specific years of the observed or bias-corrected GCM output from various forcing conditions of the impact functions.

\subsection{Full-simulation approach}

For the purpose of comparing with impact functions, the results of the conventional approach, i.e. the crop model (PRYSBI) simulation (the full-simulation), were used. In the full-simulation approach, the daily climate data were used as the input data. On the other hand, the climate data used for impact functions included only the information of climate change in the monthly scale. Therefore, the full-simulation results were independent of the impact functions.

The simulations by the full-simulation approach were carried out in accordance to the two types of forcing climate data. One was the observed climate data for 25 years from 1979 to 2003, obtained from the mesh-AMeDAS data. The estimated heading day and yield in accordance to the observed climate data were used to validate the performance of the PRYSBI model through the comparison of these estimates with the corresponding observation.

The other was the bias-corrected GCM outputs, which were available for three 20-year periods, 1981-2000, 2046-2065, and 2081-2100. These three 20-year periods corresponded to the reproduced climate with the 20th Century historical emission record and the projected future climate with emission scenarios $\mathrm{A} 1 \mathrm{~B}$ and $\mathrm{A} 2$, respectively. Though the historical emission record was given to the GCMs, the reproduced climate in a specific year did not correspond to the actual year (thus, for example, the comparison in annual temperature in 1993 between the GCM output and the observation is not appropriate). The estimated heading day and yield in accordance to the bias-corrected GCM outputs for the three periods were used to validate the impact functions.

\section{Results}

\subsection{Validation of the impact function and full- simulation}

We reproduced the historical year-to-year yield by using the full-simulation and the impact function approaches. Table 1 shows a few samples of the 6-element impact function on the regional paddy rice yield in Kanto. The parameter values of the PRYSBI

Table 1. Samples of the 6-element impact function on regional paddy rice yield in Kanto.

\begin{tabular}{|c|c|c|c|c|c|c|c|c|c|}
\hline \multirow{2}{*}{$\begin{array}{l}\text { Shift of } \\
\text { planting } \\
\text { date (days) }\end{array}$} & \multirow{2}{*}{$\begin{array}{l}\mathrm{CO}_{2} \\
(\mathrm{ppm})\end{array}$} & \multirow{2}{*}{$\begin{array}{l}\text { Percentage } \\
\text { change } \\
\text { in SR (\%) }\end{array}$} & \multirow{2}{*}{$\begin{array}{l}\text { Change in Tmax } \\
\text { and Tmin during } \\
\text { warm season }\left({ }^{\circ} \mathrm{C}\right)\end{array}$} & \multirow{2}{*}{$\begin{array}{l}\text { Change in Tmax } \\
\text { and Tmin } \\
\text { for summer }\left({ }^{\circ} \mathrm{C}\right)\end{array}$} & \multicolumn{5}{|c|}{ Estimated regional yield (t/ha) } \\
\hline & & & & & Min & $25 \%$ & $50 \%$ & $75 \%$ & $\operatorname{Max}$ \\
\hline-21 & 400 & 105 & -2.0 & 2.8 & 3.89 & 4.48 & 4.62 & 4.78 & 6.14 \\
\hline-7 & 350 & 85 & 3. & 2. & & 3.46 & & & 4.50 \\
\hline 0 & 800 & 85 & 0.5 & 4.6 & 3.50 & 4.04 & 4.16 & 4.27 & 5.03 \\
\hline 14 & 400 & 110 & 3.5 & -0.5 & 3.27 & 4.66 & 4.92 & 5.16 & 6.15 \\
\hline
\end{tabular}




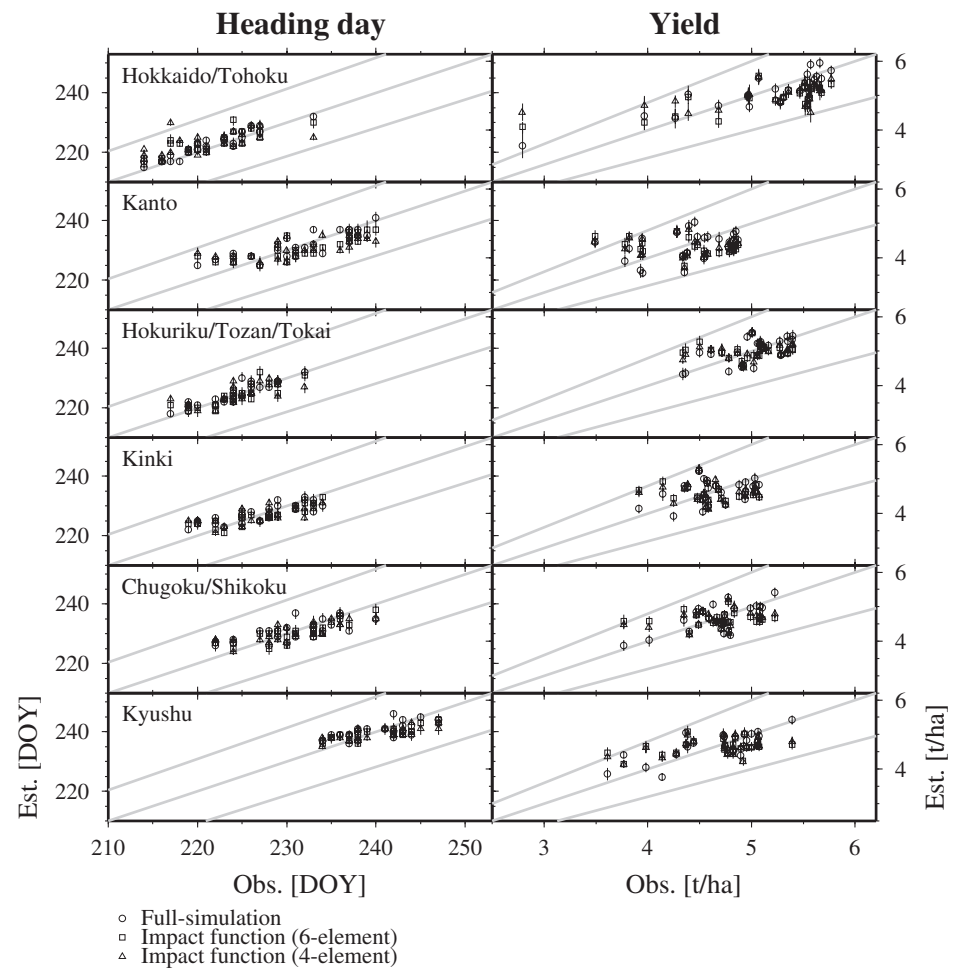

Fig. 4. Comparison of the two impact functions and the full-simulation with the observation on heading day and yield in six regions. The data for 25 years from 1979 to 2003 are presented for the observation, impact functions, and full-simulation. The gray lines indicate the $5 \%$ - and $20 \%$-error ranges for heading day and yield, respectively. The vertical bar indicates the uncertainty range (see Section 2.2).

Table 2. Coefficients of determination $\left(\mathrm{R}^{2}\right)$, root-mean-square error (RMSE), and mean-avsolute-percentage error (MAPE) between estimates and observation. FS, IF6, and IF4 indicate full-simulation, 6-element impact function, and 4-element impact function, respectively.

\begin{tabular}{|c|c|c|c|c|c|c|c|c|c|}
\hline \multirow{2}{*}{ Region } & \multicolumn{3}{|c|}{$\mathrm{R}^{2}$ [dimesnsionless] } & \multicolumn{3}{|c|}{ RMSE [day] or [t/ha] } & \multicolumn{3}{|c|}{ MAPE [\%] } \\
\hline & FS & IF6 & IF4 & FS & IF6 & IF4 & FS & IF6 & IF4 \\
\hline \multicolumn{10}{|l|}{ Heading day } \\
\hline Hokkaido/Tohoku & 0.908 & 0.676 & 0.313 & 1.7 & 3.1 & 4.2 & 0.6 & 1.1 & 1.4 \\
\hline Kanto & 0.705 & 0.661 & 0.529 & 3.0 & 3.4 & 4.1 & 1.1 & 1.3 & 1.5 \\
\hline Hokuriku/Tozan/Tokai & 0.832 & 0.720 & 0.524 & 1.6 & 2.0 & 2.6 & 0.5 & 0.6 & 0.9 \\
\hline Kinki & 0.699 & 0.708 & 0.504 & 2.4 & 2.4 & 3.1 & 0.9 & 0.9 & 1.1 \\
\hline Chugoku/Shikoku & 0.530 & 0.684 & 0.598 & 3.1 & 2.7 & 3.0 & 1.1 & 0.9 & 1.1 \\
\hline Kyushu & 0.529 & 0.664 & 0.558 & 2.6 & 2.6 & 2.9 & 1.0 & 1.0 & 1.0 \\
\hline Average & 0.701 & 0.686 & 0.504 & 2.4 & 2.7 & 3.3 & 0.9 & 1.0 & 1.2 \\
\hline \multicolumn{10}{|l|}{ Yield } \\
\hline Hokkaido/Tohoku & 0.747 & 0.565 & 0.279 & 0.3 & 0.5 & 0.6 & 5.9 & 8.8 & 10.0 \\
\hline Kanto & 0.166 & 0.146 & 0.007 & 0.4 & 0.5 & 0.5 & 8.4 & 10.7 & 10.1 \\
\hline Hokuriku/Tozan/Tokai & 0.470 & 0.001 & 0.102 & 0.3 & 0.3 & 0.3 & 4.1 & 5.9 & 5.2 \\
\hline Kinki & 0.178 & 0.044 & 0.000 & 0.3 & 0.4 & 0.4 & 5.8 & 7.4 & 7.3 \\
\hline Chugoku/Shikoku & 0.467 & 0.005 & 0.109 & 0.3 & 0.4 & 0.3 & 4.8 & 6.5 & 6.2 \\
\hline Kyushu & 0.567 & 0.116 & 0.199 & 0.3 & 0.4 & 0.4 & 5.1 & 7.6 & 7.4 \\
\hline Average & 0.433 & 0.146 & 0.116 & 0.3 & 0.4 & 0.4 & 5.7 & 7.8 & 7.7 \\
\hline
\end{tabular}




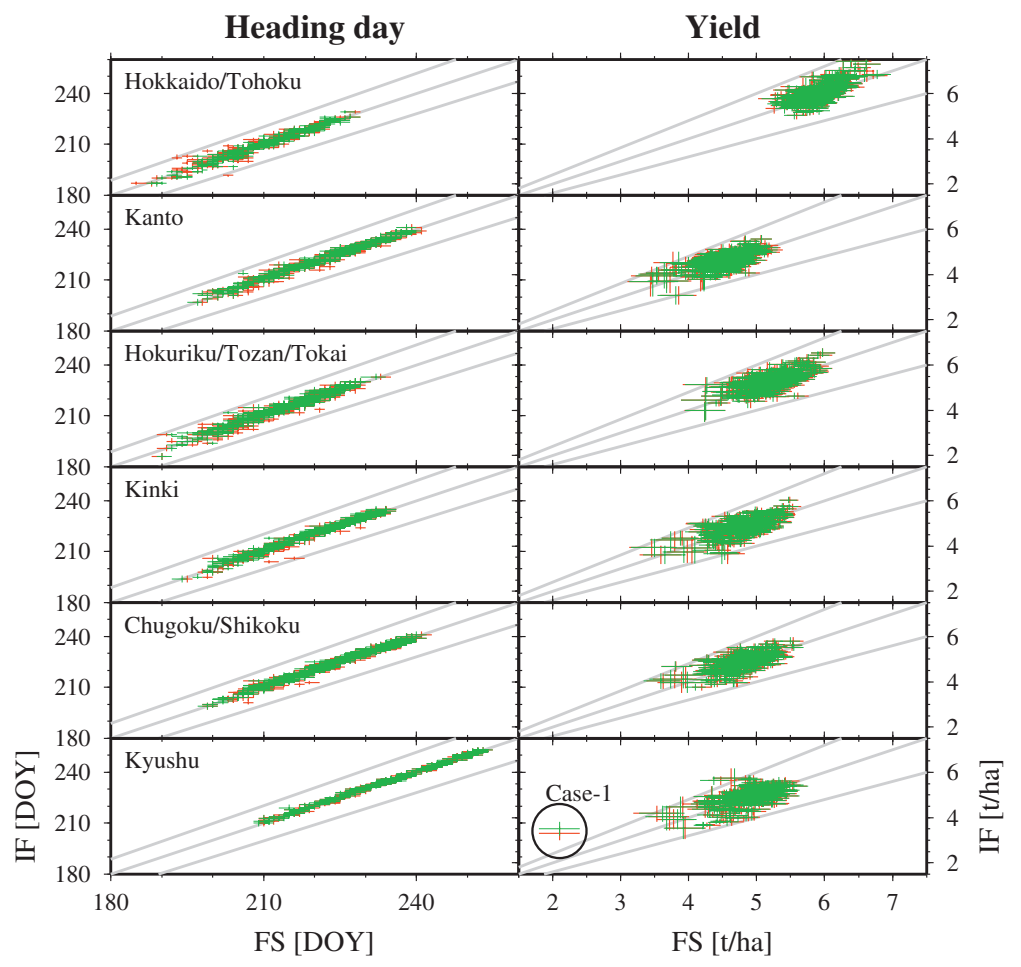

Fig. 5. Comparison of the two impact functions (y-axis: green, 6-element; red, 4-element) with the fullsimulation (x-axis) on heading day and yield in six regions. To avoid too much plots in the figure, the data at the time when the change in the warm season temperature was above $1.5^{\circ} \mathrm{C}$ regardless of the insolation, atmospheric $\mathrm{CO}_{2}$ concentration, and planting date are presented with a 20 -interval after sorting according to the temperature change. The data were selected from the periods of 1981-2000, 2046-2065, and 2081-2100 for the full-simulation and the corresponding impact functions. The gray lines indicate the $5 \%$ - and $20 \%$-difference ranges for heading day and yield, respectively. The vertical (horizontal) bar indicates the uncertainty range for the impact functions (the full-simulation).

model were calibrated on the basis of the heading day and yield data at the 13 odd years from 1979 to 2003 (i.e. 1979, 1981, .., 2003) (Iizumi et al., 2009). Taking this into account, we validated the impact functions and full-simulation on the basis of the heading and yield data for all 25 years from 1979 to 2003 . The median and percentiles of the PPE members in each prefecture were subsequently compiled and averaged over the prefectures to obtain the regional data.

Fig. 4 shows the comparison of the reproduced regional yield with the observation. The simulated heading day was also presented to check the relevance of the simulation. The comparison of the heading day shows that the two impact functions and the full-simulation were comparable with the observation. The two impact functions often underestimated the yield when the observed yield was high, but also often overestimated it when the observed yield was low.

Table 2 is a statistical summary of the comparison. Focusing on the regional average, the calculated statistics on heading day were as follows: full-simulation (FS), 0.701; 6-element impact function (IF6), 0.686; and 4-element impact function (IF4), 0.504 for the coefficient of determination $\left(\mathrm{R}^{2}\right)$; FS, 2.4 days; IF6, 2.7 days; and IF4, 3.3 days for the root-mean-square (RMS) error; FS, 0.9\%; IF6, 1.0\%; and IF4, 1.2\% for the mean-absolute-percentage (MAP) error. On the other hand, the calculated statistics on yield were as follows: FS, 0.433; IF6, 0.146; and IF4, 0.116 for $\mathrm{R}^{2}$; FS, $0.3 \mathrm{t} / \mathrm{ha}$; IF6, $0.4 \mathrm{t} / \mathrm{ha}$; and IF4, $0.4 \mathrm{t} / \mathrm{ha}$ for the RMS error; FS, 5.7\%; IF6, 7.8\%; and IF4, 7.7\% for the MAP error. The $\mathrm{R}^{2}$ values of the full-simulation in the Kanto and Kinki regions were lower than those elsewhere; however, the RMS error values in these 
Table 3. Coefficients of determination $\left(\mathrm{R}^{2}\right)$, root-mean-suare difference (RMSD), and mean-avsolute-percentage difference (MAPD) between impact functions and full-simulation. IF6 and IF4 indicate impact function (6-element) and impact function (4-element), respectively.

\begin{tabular}{lcccccc}
\hline \multirow{2}{*}{ Region } & \multicolumn{2}{c}{$\mathrm{R}^{2}$ [dimesnsionless] } & \multicolumn{2}{c}{ RMSD [day] or [t/ha] } & \multicolumn{2}{c}{ MAPD [\%] } \\
\cline { 2 - 8 } & IF6 & IF4 & IF6 & IF4 & IF6 & IF4 \\
\hline Heading day & & & & & & \\
$\quad$ Hokkaido/Tohoku & 0.949 & 0.918 & 2.1 & 2.6 & 0.7 & 1.0 \\
Kanto & 0.979 & 0.965 & 2.0 & 2.2 & 0.7 & 0.8 \\
Hokuriku/Tozan/Tokai & 0.958 & 0.927 & 2.2 & 2.6 & 0.8 & 0.9 \\
Kinki & 0.981 & 0.969 & 1.7 & 1.9 & 0.6 & 0.7 \\
Chugoku/Shikoku & 0.985 & 0.978 & 1.5 & 1.7 & 0.5 & 0.5 \\
Kyushu & 0.960 & 0.964 & 3.4 & 3.2 & 1.0 & 0.9 \\
Average & 0.969 & 0.954 & 2.1 & 2.4 & 0.7 & 0.8 \\
Yield & & & & & & \\
Hokkaido/Tohoku & 0.649 & 0.652 & 0.30 & 0.29 & 3.9 & 3.8 \\
Kanto & 0.513 & 0.485 & 0.29 & 0.30 & 5.0 & 5.2 \\
Hokuriku/Tozan/Tokainyyyyyyyyyyyy & 0.583 & 0.561 & 0.29 & 0.30 & 4.4 & 4.5 \\
Kinki & 0.633 & 0.618 & 0.27 & 0.28 & 4.5 & 4.6 \\
Chugoku/Shikoku & 0.619 & 0.594 & 0.27 & 0.28 & 4.5 & 4.6 \\
Kyushu & 0.516 & 0.491 & 0.30 & 0.31 & 4.8 & 4.9 \\
Average & 0.586 & 0.567 & 0.29 & 0.29 & 4.5 & 4.6 \\
\hline
\end{tabular}

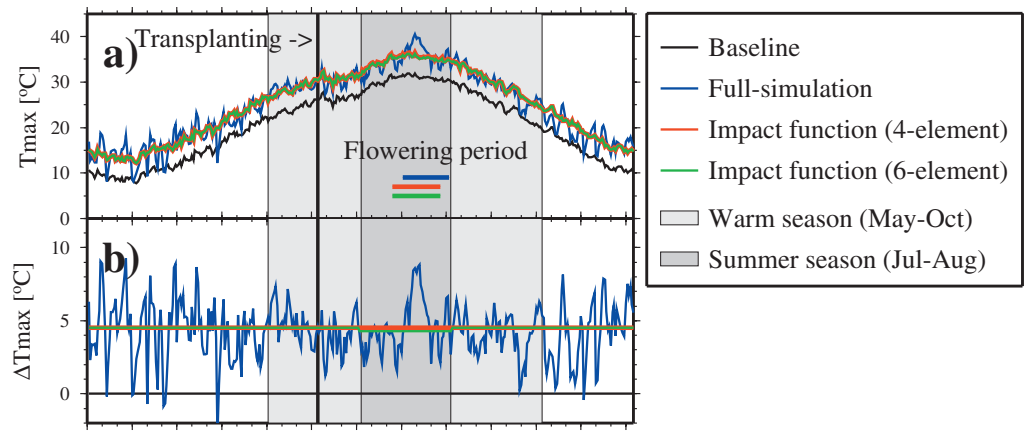

Fig. 6. Daily maximum temperature (a) and temperature anomaly (relative to the baseline) (b) for Case 1 in Fig. 5. The transplanted date and the flowering period are also indicated.

areas were similar. All $\mathrm{R}^{2}$ values of the two impact functions were lower than 0.5 except for the 6-element impact function in Hokkaido/Tohoku.

\subsection{Comparison of the impact functions with the full-simulation}

To validate the impact functions under the warming condition, the two impact functions were compared to the full-simulation. Fig. 5 shows the comparison in six regions when the change in the warm season temperature was above $1.5^{\circ} \mathrm{C}$ regardless of the insolation, atmospheric $\mathrm{CO}_{2}$ concentration, and planting date. The comparison of the heading day indicates that the two impact functions closely resemble the full-simulation in most cases. In addition, the yield of the two impact functions fairly resembles the full-simulation. However, the two impact functions often overestimated the yield in all regions except for Hokkaido/Tohoku when the yield of the full-simulation was low (Case 1 being a typical example).

Table 3 is a statistical summary of the comparison. Focusing on the regional average, the calculated statistics on heading day were as follows: IF6, 0.969 and IF4, 0.954 for $\mathrm{R}^{2}$; IF6, 2.1 days and IF4, 2.4 days for the RMS difference; IF6, $0.7 \%$ and IF4, $0.8 \%$ for the MAP difference. On the other hand, the calculated statistics on yield were as follows: IF6, 0.586 and IF4, 
0.567 for $\mathrm{R}^{2}$; IF6, $0.29 \mathrm{t} / \mathrm{ha}$ and IF4, $0.29 \mathrm{t} / \mathrm{ha}$ for the RMS difference; IF6, $4.5 \%$ and IF4, $4.6 \%$ for the MAP difference.

\section{Discussion}

\subsection{Noteworthy differences between the impact functions and the full-simulation}

The results showed that the impact functions were generally comparable to the full-simulation, although remarkable differences in the simulated yield between them sometimes emerged when the yield loss was significant. Case 1 is a typical example and the MAP difference in this case was over $20 \%$. Fig. 6 shows the climate data in Case 1 . The extremely high temperature $\left(>33^{\circ} \mathrm{C}\right)$ that continued for 22 days in July to August was found in the climate data of the full-simulation (Figs. 6a and b), although no such extreme event was found in the climate data of the impact functions. All simulated flowering periods included the 22 days. As a result, the calculated average daily maximum temperatures during the flowering period were $37.4^{\circ} \mathrm{C}$, $35.6^{\circ} \mathrm{C}$, and $35.8^{\circ} \mathrm{C}$ for FS, IF6, and IF4, respectively, while the simulated spikelet sterilities caused by heat stress were $66.0 \%, 34.8 \%$, and $38.8 \%$ for FS, IF6, and IF4, respectively. Consequently, the anticipated yield for FS decreased to $2.1 \mathrm{t} / \mathrm{ha}$, although the yields remained at $3.5 \mathrm{t} / \mathrm{ha}$ for IF6 and $3.3 \mathrm{t} / \mathrm{ha}$ for IF4 respectively. This indicates that the impact functions failed to capture the yield response to an extremely high temperature during the flowering period.

\subsection{Limitations of the impact functions}

The accuracy of the full-simulation to reproduce the historical regional yield differed by area and was relatively low in some areas (e.g. Kanto and Kinki). Therefore, it should be noted that the impact functions under the warming condition include the error between the full-simulation and the corresponding observation in addition to the difference between the full-simulation and the corresponding impact function. Nevertheless, considering results showing that the impact functions were often comparable to the observation and the full-simulation, they are applicable to the assessment of the impact of average climate change on the regional yield. However, the impact functions failed to capture the yield loss caused by heat stress, prompted by the extremely high temperature within a short period. This indicates that the application of the impact functions to the assessment of the impact of extreme climate events is not permissible. In addition, the results also show that the impact functions are relatively unreliable in reproducing the interannual variation of the regional yield, although they were capable of reproducing the mean state of the regional yield. Therefore, assessing the impact of the average climate change on the longterm (e.g. 25 years), the averaged regional yield is the area where the impact functions can apply.

In addition, there is modeling uncertainty on the spikelet sterility caused by heat stress arising from the experimental design (chamber or field), the difference in the micrometeorological conditions inside and outside the crop canopy, and the climate acclimation (Hasegawa et al., 2007). This uncertainty relates to both the impact functions and the full-simulation. Certainly, the PRYSBI model is based on knowledge obtained from the chamber experiments and considers the uncertainty of the spikelet sterility simulation associated with the model parameters. Nevertheless, further inclusion of modeling uncertainty may still be required to provide a more reliable assessment on a regional scale.

Finally, the capability of climate models in response to short-term and extreme phenomena is not very reliable except for a few very high-resolution climate models (e.g. the $20-\mathrm{km}$ mesh size global or regional climate model: Sasaki et al., 2005; Kurihara et al., 2005). Under such circumstances, the combination of the impact functions and coarse-resolution climate models is permissible and appropriate for the quicklook-like assessment of the impact of average climate change. Similarly, the combination of full-simulation and very high-resolution climate models is adequate to assess the impacts of extreme climate events and interannual climate variation in detail.

\section{Concluding remarks}

Two types of impact functions on the regional yield of paddy rice in six regions of Japan were developed and validated. As a result of the validation, it was concluded that the impact functions are applicable to assess the impact of average climate change on the long-term (e.g. 25 year) average regional yield. However, the impact functions are not applicable to assess the impacts of extreme climate events and interannual climate variation on the regional yield. The developed impact functions will be implemented to the integrated model (i.e. AIM/Impact[Policy]) and used to examine the target level of stabilization. The details will be reported in the near future. 


\section{Acknowledgements}

We would like to acknowledge the PCMDI for collecting and archiving the model data and the CCSR, University of Tokyo, for distributing the data of the MIROC3.2.HIRES. The IPCC Data Archive at the Lawrence Livermore National Laboratory is supported by the Office of Science, U.S. Department of Energy. This study was supported by the Global Environmental Research Fund (S-4 and S-5-3) from the Ministry of the Environment, Japan. Computation was partially carried out on the SGI Altix3700 at the Computer Center for Agriculture, Forestry, and Fisheries Research, MAFF, Japan.

\section{References}

Delworth, T. L., Rosati, A., Stouffer, R. J., Dixon, K. W., Dunne, J., Findell K. L., Ginoux, P., Gnanadesikan, A., Gordon, C. T., Griffies, S. M., Gudgel, R., Harrison, M. J., Held, I. M., Hemler, R. S., Horowitz, L. W., Klein, S. A., Knutson, T. R., Lin, S. J., Ramaswamy, V., Schwarzkopf, M. D., Sirutis, J. J., Spelman, M. J., Stern, W. F., Winton, M., Wittenberg, A. T., and Wyman, B., 2006: GFDL's CM2 global coupled climate models -Part 1: Formulation and simulation characteristics. J. Clim., 19, 643-674.

Gordon, H. B., Rotstayn, L. D., McGregor, J. L., Dix, M. R., Kowalczyk, E. A., O'Farrell, S. P., Waterman, L. J., Hirst, A. C., Wilson, S. G., Collier, M. A., Watterson, I. G., and Elliott, T. I., 2002: The CSIRO Mk3 climate system model. CSIRO Atmospheric Research Technical Paper No. 60, CSIRO, 130pp.

Flato, G. M., Boer, G. J., Lee, W. G., McFarlane, N. A., Ramsden, D., Reader, M. C., and Weaver, A. J., 2000: The Canadian center for climate modeling and analysis global coupled model and its climate. Clim. Dyn., 16, 451-467.

Hijioka, Y., Masui, T., Takahashi, K., Matsuoka, Y., and Harasawa, H., 2006a: Development of a support tool for greenhouse gas emissions control policy to help mitigate the impact of global warming. Environ. Econ. Pol. Stud., 3, 331-345.

Hijioka, Y., Takahashi, K., and Kubota, I., 2006b: Country-specific impact assessment of potential productivity changes of rice and wheat under greenhouse gas stabilization targets utilizing integrated assessment model. J. Environ. Info. Sci., 20, 19-24.

Hanasaki, N., Masutomi, Y., Takahashi, K., Hijioka, Y., Harasawa, H., and Matsuoka, Y., 2007: Develop- ment of a global water resources scheme for climate change policy support models. J. Environ. Info. Sci., 35, 367-374.

Hasegawa, T., 2007: Predicting the impact of global warming on paddy rice yield. In Proceedings of the workshop on research for the effects of climate change on agriculture in the Kyushu region 2007, Chikugo, Fukuoka, 1-2 October, 2007, 7-12 (in Japanese).

Horie, T., 1993: Predicting the effects of climate variation and elevated $\mathrm{CO}_{2}$ on rice yield in Japan. J. Agric. Meteorol., 48, 567-574.

Iizumi, T., Yokozawa, M., and Nishimori, M., 2009: Parameter estimation and uncertainty analysis of a large-scale crop model for paddy rice: Application of a Bayesian approach. Agric. Forest Meteorol., 149, 333-348.

Iizumi, T., Nishimori, M., and Yokozawa, M., 2008: Combined equations for estimating global solar radiation: Projection of radiation field over Japan under global warming condition by statistical downscaling. J. Agric. Meteorol., 64, 9-23.

IPCC, 2000: Special Report on Emission Scenario: A special report of working group III of the Intergovernmental Panel on Climate Change (ed. by Nakicenovic, N., and Swart, R.). Cambridge University Press, Cambridge, U.K., 570pp.

IPCC, 2007: Climate Change 2007: The Physical Science Basis. Contribution of Working Group I to the Fourth Assessment Report of the Intergovernmental Panel on Climate Change (ed. by Solomon, S., Qin, D., Manning, M., Chen, Z., Marquis, M., Averyt, K. B., Tignor, M., and Miller, H. L.). Cambridge University Press, Cambridge, United Kingdom and New York, NY, USA, 996pp.

Kurihara, K., Ishihara, K., Sasaki, H., Fukuyama, Y., Saitou, H., Takayabu, I., Murazaki, K., Sato, Y., Yukimoto, S., and Noda, A., 2005: Projection of climatic change over Japan due to global warming by high-resolution regional climate model in MRI. SOLA, 1, 97-100.

K-1 model developers, 2004: K-1 coupled GCM (MIROC) description (ed. by Hasumi, H., and Emori, S.), K-1 Technical Report 1, 34pp.

MAFF, 1998: New method for calculating normal yield of paddy rice per decare. Association of Agriculture and Forestry Statistics, 143pp. (in Japanese).

Meehl, G. A., Covey, C., Delworth, T., Latif, M., McAvaney, B., Mitchell, J. F. B., Stouffer, R. J., and 
Taylor, K. E., 2007: The WCRP CMIP3 multimodel dataset: A new era in climate change research. Bull. Amer. Meteor. Soc., 88, 1383-1394.

Nakagawa, H., Horie, T., and Matsui, T., 2003: Effects of climate change on rice production and adaptive technologies. In Rice Science: Innovations and impact for livelihood (ed. by Mew, T. W., Brar, D. S., Peng, S., Dawe, D., and Hardy, B.). IRRI and Chinese Academy of Engineering and Chinese Academy of Agricultural Sciences, 635-658.

Okada, M., Iizumi, T., Nishimori, M., and Yokozawa, M. 2009: Mesh climate change data of Japan Ver. 2 for climate change impact assessments under IPCC SRES A1B and A2. J. Agric. Meteorol., 65, 97-109.

Seino, H., 1993: An estimation of distribution of the meteorological elements using GIS and AMeDAS data. J. Agric. Meteorol., 48, 379-383.

Sasaki, H., Kurihara, K., and Takayabu, I., 2005: Comparison of climatic reproducibility between a super-high-resolution atmosphere general circulation model and a meteorological research institute regional climate model. SOLA, 1, 81-84.

Tao, F., Yokozawa, M. and Zhaug, Z., 2009: Modelling the impacts of weather and climate variability on crop productivity over a large area: I. A new process-based model development, optimization, and uncertainties analysis. Agric. Forest Meteorol. 149, 831-850.

Toritani, H., Yonemura, S., and Yokozawa, M., 1999: Potential rice yield in the $21^{\text {st }}$ century in Japan under the climate-change scenario based on MRI-CGCM. J. Jpn. Agric. Syst. Soc., 15, 8-16.

United Nations, 1992: United Nations Framework Convention on Climate Change. United Nations, New York, 24pp.

Wilby, R. L., Charles, S. P., Zorita, E., Timbal, B., Whetton, P., and Mearns, L. O., 2004: Guidelines for use of climate scenarios developed from statistical downscaling methods. Supporting material of the IPCC, 1-27.

Yokozawa, M., Iizumi, T., Kotera, A., Sakamoto, T., and Nakagawa, H., 2006: Development of crop model for paddy rice to estimate prefectural-scale average yield. Proceedings of the Joint Meeting on Environmental Engineering in Agriculture 2006, Sapporo, Hokkaido, 11-15 September, 2006, 1 (in Japanese).

Yukimoto, S., and Noda, A., 2002: Improvements of the Meteorological Research Institute Global OceanAtmosphere Coupled GCM (MRI-CGCM2) and its climate sensitivity. CGCR's Supercomput. Act. Rep., 10, 37-44. 


\title{
統合影響評価モデルのための日本の 地域水稲収量影響関数の開発
}

\author{
飯泉仁之直・横沢正幸・西森基貴
}

( 農業環境技術研究所)

約

\begin{abstract}
要
本研究では日本の 6 地域における地域水稲収量につ いて2 種類の影響関数を開発・検証した。つは単純で, もう一つはやや詳細である。影響関数は (1) 様々な強制 力の状態に対する, 関心を寄せるある量 (本研究では地 域水稲収量) の応答についての参照表であり, (2) 機構 的で計算機負荷の大きいモデルによって作成される，(3) シミュレーション時間の短縮のために統合影響評価モデ ルに実装されることが特徵である。開発された影響関数 は統合影響評価モデルに組み込まれ, 温室効果ガス排 出の安定化レベルを検討するために用いられる。本研究 では, 影響関数を観測值と慣行的な作物モデルシミュレ ーションの結果 (フルシミュレーション) と比較した。や やに詳細な (単純な) 影響関数の収量と観測值との平均
\end{abstract}

絶対パーセント誤差は 7.8\% (7.7\% ) だった。また，温 暖化条件化では, 僅かに詳細な (単純な) 影響関数の 収量とフルシミュレーションとの平均絶対パーセント差は $4.5 \%$ (4.6\% ) だった。これらの差の多くは 2 ケ月より短 い期間での気温の変動によって生じた。これらの結果か ら, 気候の平均的な変化が地域収量に及ぼす影響を評 価することに影響関数を用いることは可能と考えられる。 しかしながら, 気候の極端現象や年々変動が地域収量に 及ぼす影響を評価するためには影響関数は必ずしも信頼 性の高いツールとは言えない。

キーワード：影響関数, 地域水稲収量, 統合影響評価 モデル, 日本 